\title{
Diversifikasi pengolahan singkong untuk peningkatan kesejahteraan masyarakat
}

\author{
Diversification of Cassava Processing for Improving Community Welfare \\ Khoirin Maghfiroh $^{1}$, R.R. Sri Karuniari Nuswardhani ${ }^{1)}$ \\ ${ }^{\mathbf{1}}$ Fakultas Pertanian, Universitas Yudharta Pasuruan \\ Email : ri2nkhoir@gmail.com \\ Informasi Artikel: \\ Dikirim: 10/09/2019; ditinjau: 15/09/2019; disetujui: 30/09/2019
}

\begin{abstract}
The community partnership program (PKM) in the cassava processing effort without producing waste was carried out together with PKK ladies groups namely PKK RT.4 RW 1 Loring Sukopuro Jabung District Malang Regency. The lack of technological knowledge causes the processing of cassava is not optimal. Cassava processing still uses simple technology. Most cassava is sold in raw form and some is sold in processed chips, besides that there are no handlers related to waste produced from cassava preparations. But on the other hand, abundant cassava production. This program aims to form an independent business group in the development of processed cassava to produce nutritious products without producing waste. The method of approach used in PKM is the Participatory Rural Appraisal (PRA) approach, which involves partner groups in activities. As for the implementation of this PKM activities include: counseling, training, hands-on practice, and assistance. The results of this program are increasing partners 'knowledge in processing cassava into nutritional products based on waste utilization, knowledge of partners' skills in processing cassava into nutritional products based on waste utilization, partners are able to utilize appropriate technology transfer, and improving management and marketing capabilities.
\end{abstract}

Key words : diversification, processing, cassava

\begin{abstract}
ABSTRAK
Program kemitraan masyarakat (PKM) dalam upaya pengolahan Singkong tanpa menghasilkan limbah ini dilaksanakan bersama kelompok ibu-ibu PKK yaitu PKK RT.4 RW 1 Loring Sukopuro Kecamatan Jabung Kabupaten Malang. Rendahnya pengetahuan teknologi menyebabkan pengolahan Singkong belum optimal. Pengolahan Singkong masih menggunakan teknologi yang sederhana. Sebagian besar Singkong dijual dalam bentuk mentah dan sebagian lain dijual dalam bentuk olahan keripik, selain itu belum terdapat penangan terkait limbah yang dihasilkan dari olahan Singkong. Namun di sisi lain produksi Singkong melimpah. Program ini bertujuan membentuk kelompok usaha mandiri dalam pengembangan olahan Singkong menghasilkan produk bergizi tanpa menghasilkan limbah. Metode pendekatan yang dipakai dalam PKM adalah metode pendekatan partisipasi kelompok atau Partisipatory Rural Apprasial (PRA), yaitu melibatkan kelompok mitra dalam kegiatan. Adapun dalam pelaksanaannya kegiatan PKM ini meliputi: penyuluhan, pelatihan, praktek langsung, dan pendampingan. Hasil dari
\end{abstract}


program ini adalah peningkatan pengetahuan mitra dalam mengolah Singkong menjadi produk bergizi berbasis pemanfaatan limbah, pengetahuan ketrampilan mitra dalam mengolah Singkong menjadi produk bergizi berbasis pemanfaatan limbah, mitra mampu memanfaatkan alih teknologi tepat guna, dan peningkatan kemampuan manajemen dan pemasaran.

Kata kunci : diversifikasi, pengolahan, singkong

\section{PENDAHULUAN}

Desa Sukopuro merupakan salah satu dari 15 desa yang terdapat di kecamatan Jabung kabupaten Malang. Secara geografis luas wilayah desa Sukopuro adalah 630.935 ha. Batas wilayah desa Sukopuro adalah sebelah utara desa Sidomulyo, sebelah timur desa Ngadirejo, sebelah selatan Kenongo, dan sebelah barat Sidomulyo. Pekerjaan sebagian besar penduduk bekerja pada sektor informal. Hal ini disebabkan karena sekitar 1011 penduduk tamatan SLTP dan sekitar 600 penduduk tamatan SD. Rendahnya kualitas pendidikan formal menyebakan inovasi dan pengolahan produk bergizi serta teknik pengelolaan keuangan rendah. Pertumbuhan Singkong di desa Sukopuro relative mudah sehingga ketersediaan Singkong di desa tersebut melimpah. Singkong dapat tumbuh di pekarangan warga dan tegal / lading. Lahan penanaman Singkong seluas 9 ha.

Program swasembada tersebut dapat mendorong berbagai sektor lokal untuk melakukan berbagai pengembangan pengolahan bahan pangan. Pengembangan sektor lokal merupakan langkah awal pembentukan kemandirian dalam hal pemenuhan kebutuhan pangan. Pembentukan kemadirian terhadap kebutuhan bahan pangan dapat mengurangi ketidak merataan distribusi bahan pangan utamanya bahan pangan serat tinggi. Salah satu bahan serat tinggi yang merupakan komoditi lokal Indonesia adalah singkong. Pertumbuhan Singkong relatif mudah, tidak membutuhkan banyak pengairan. Terkadang Singkong dapat tumbuh sendiri tanpa diberi pengairan (Dep.Kes. RI. 1972).
Transfer teknologi yang akan diberikan pengusul akan memudahkan kelompok usaha dalam proses produksi, membuat kelompok usaha ini lebih berkembang dan lebih kreatif. Disamping itu diversifikasi produk berupa pelatihan pembuatan mie mocaf, nata de cassava dan gula cair yang memanfaatkan Singkong sekaligus limbahnya membuat produk yang dihasilkan memiliki nilai gizi tinggi, lebih bervariatif serta harga jual tinggi. Mocaf (modified cassava flour) merupakan produk hasil pengolahan singkong yang diproses menggunakan prinsip memodifikasi sel ubi kayu dengan cara fermentasi. Mikroba yang tumbuh menyebabkan perubahan karakteristik pada tepung yang dihasilkan, yaitu berupa naiknya viskositas, kemampuan gelasi, daya rehidrasi, dan kemudahan melarut. Mikroba juga menghasilkan asamasam organik, terutama asam laktat yang akan terimbibisi dalam tepung, dan ketika tepung tersebut diolah akan dapat menghasilkan aroma dan citra rasa khas, yang dapat menutupi aroma dan citra rasa singkong yang cenderung tidak menyenangkan konsumen (Hersoelistyorini dkk. 2015). Subagio (2009) menyampaikan bahwa semua jenis singkong dapat diolah menjadi tepung mocaf. Yang terbaik singkong berasam sianida rendah, maksimal $1 \%$. Sianida-penyebab rasa pahit dan aroma langu mudah terbuang saat fermentasi sehingga cita rasa pahit pada tepung pun hilang. Singkong ideal yang sebaiknya digunakan adalah varietas singkong yang bisa dimakan, berumur sekitar 8-12 bulan, Masih segar, tidak busuk, dan tidak bercak-bercak hitam, dan lama penyimpanan maksimal 2 hari. Tepung mocaf dengan kadar 
amilosa rendah memiliki kadar amilopektin tinggi. Amilopektin bersifat merangsang terjadinya proses mekar (puffing), sehingga produk pangan yang dihasilkan akan bersifat ringan, porus, garing, dan renyah. Tepung mocaf dengan kadar amilosa rendah cocok digunakan sebagai bahan baku pembuatan cookies (Zulaidah, 2011). Tepung mocaf juga dapat disubstitusikan dengan tepung terigu untuk pengolahan mie dengan perbandingan yang direkomendasikan untuk tepung terigu $90 \%$ dan mocaf $10 \%$ dapat menghasilkan mie yang kenyal. Hal tersebut disebabkan rendahnya amilosa sehingga air dapat terserap ke dalam molekul pati (Iva et al., 2013). Hal ini berlaku sebaliknya pada kandungan protein yang tinggi dapat memicu daya putus mie mocaf (Riki et al. 2013). Tepung mocaf memiliki sifat gelatinasi dengan cara membentuk gel, hal tersebut disebabkan kadar amilopektin yang tinggi dan kadar amilosa yang rendah (Charles et al., 2005).

Selain pemanfaatan pati Singkong melalui mocaf, air cucian singkong (endapan pati) juga dapat diolah menjadi nata. Nata yang dihasilkan berupa nata de cassava. Nata de cassava merupakan produk pangan tinggi serat yang salah satunya dapat dimanfaatkan sebagai hidangan pencuci mulut. Adapun kandungan hasil samping dari Singkong yang dapat dimanfaatkan sebagai nata, sebagai berikut : glukosa 0,185 mg/L, nitrogen 182 $\mathrm{mg} / \mathrm{L}$, dan $\mathrm{pH} 5$ - 5,5 (Misgiyarta, 2013). Pengolahan Singkong menjadi dua produk tersebut akan menghasilkan limbah berupa kulit Singkong. Lapisan dalam kulit Singkong dapat dimanfaatkan sebagai gula cair. Gula cair dari kulit Singkong dapat diperoleh melalui proses sakarifikasi dan evaporasi. Gula cair dari kulit Singkong terfermentasi B.licheniformis diketahui memiliki kadar kalori yang rendah sebesar $113 \mathrm{kkal} / 100$ gram, jika dibandingkan dengan gula tebu sebesar $364 \mathrm{kkal} / 100$ gram (Rahmawati et al., 2017). Kulit Singkong dapat digunakan sebagai bahan baku pembuatan gula cair dengan karena gula kompleks dapat dirubah menjadi glukosa melalui proses likuifikasi dan sakarifikasi dengan enzim alfa amylase dan glukoamilase (Putra et al., 2012). Enzim diperlukan dalam proses pengolahan gula cair. Enzim $\alpha$-amilase diperlukan dalam proses likuifikasi dan secara optimum dapat bekerja selama 1,5 jam untuk menghasilkan gula pereduksi sebesar 24,64\% dengan DE sebesar 91,80 (Yunianta et al., 2010). Sakarifikasi merupakan proses lanjutan dalam pengolahan gula cair. Proses ini melibatkan enzim glukoamilase yang dapat menginversi konfigurasi dari rantai yang pecah serta memecah ikatan glikosida (Pratam, 2015). Teknik pengolahan tersebut dapat dijadikan sebagai percontohan proses pengolahan Singkong yang menghasilkan produk bergizi sekaligus pemanfaatan limbahnya serta sistem manajemen dan pengelolaan keauangan yang lebih baik.

Berdasarkan hasil analisis di atas dan kesepakatan dengan kelompok mitra, maka beberapa permasalahan yang difokuskan dalam program ini adalah : 1) Pengetahuan tentang teknologi pengembangan olahan bahan pangan rendah, 2) Produk yang dihasilkan dalam bentuk mentah, 3) Manajemen usaha pengolahan dan pemasaran rendah, 4) Pengetahuan terkait pengamasan rendah, 5) Pengelolaan keuangan lemah, 6) Kualitas SDM rendah.

Adapun tujuan dari program ini adalah: (1) Membentuk kelompok usaha yang memiliki pengetahuan tentang teknologi pengolahan nata de cassava dan gula cair sehingga mereka dapat mengoptimalkan potensi sumberdaya lokal. (2) Meningkatkan kemandirian kelompok usaha dalam hal pengembangan produk bergizi berbasis pemanfaatan limbah menggunakan sumberdaya lokal yang ada. (3) Menghasilkan kelompok usaha yang mampu menjadi wirausaha mandiri dalam usaha pembuatan mie mocaf, nata de cassava dan gula cair sehingga dapat dijadikan alternatif 
khususnya dalam menambah penghasilan keluarga. (4) Meningkatkan kemampuan manajemen dan pengelolaan keuangan sehingga dapat mengatur usaha mandirinya. (5) Membuat kawasan percontohan usaha mikro untuk pengembangan produk bergizi berbasis pemanfaatan limbah di Kecamatan Jabung (6) Target luaran secara akademis untuk pendidikan yaitu publikasi artikel ilmiah dan buku Petunjuk Praktis Pengolahan bahan pangan dari Singkong disertai pemanfaatan limbahnya.

\section{METODE PELAKSANAAN}

\section{Bahan}

Bahan untuk pembuatan mie mocaf, nata de cassava dan gula cair adalah Singkong, telor, tepung terigu tinggi protein, air, bawang putih, garam, asam sitrat, enzim alfa amilase, enzim betamilase, enzim glukoamilase, starter mocaf, gula pasir, dan arang.

Alat

Alat - alat yang digunakan terdiri dari baskom, nampan, oven, pisau, timbangan, spatula, $\mathrm{pH}$ meter, gelas ukur, pasta maker, mesin mixer gula cair, refraktometer, termometer, pipet tetes, press sealer, parut Singkong, dan pemotong chips.

\section{Teknik pelaksanaan}

Untuk mengatasi permasalahan yang dihadapi mitra diperlukan metode pendekatan yang sesuai dengan yang dibutuhkan. Metode pendekatan yang dipakai dalam PKM adalah metode pendekatan partisipasi kelompok atau Partisipatory Rural Apprasial (PRA), yaitu melibatkan kelompok mitra dalam kegiatan. Adapun dalam pelaksanaannya kegiatan PKM ini meliputi: penyuluhan, pelatihan, praktek langsung, dan pendampingan. Tahapantahapan pelaksanaan PKM ini dijelaskan sebagai berikut:1) Penyuluhan yaitu dengan cara mengumpulkan mitra yang terdiri kelompok ibu-ibu PKK, 2) Pelatihan yaitu pelatihan terhadap penerapan teknologi dan manajemen disertai dengan praktek langsung, 3) Praktik langsung melalui kegiatan demontrasi yaitu pembuatan mie cassava, nata de cassava dan gula cair, cara pengemasannya serta praktik pembukuan keuangan, 4) Pendampingan dalam kegiatan praktik dan pendampingan dalam penerapan iptek yang sudah diberikan dalam usaha

\section{HASIL DAN PEMBAHASAN}

\section{Survey}

Sebelum kegiatan PKM dilaksanakan, terlebih dahulu dilakukan kegiatan survey lokasi dan kunjungan kepada mitra maupun anggota. Hal tersebut untuk membahasa langkah - langkah yang perlu dilakukan agar program berjalan dengan lancar. Setelah itu dibuat rumusan permasalahn beserta solusinya. Selain itu juga dilakukan survey terkait alat dan bahan yang diperlukan untuk pengolahan Singkong, kemudian dilakukan pendataan alat dan bahan.

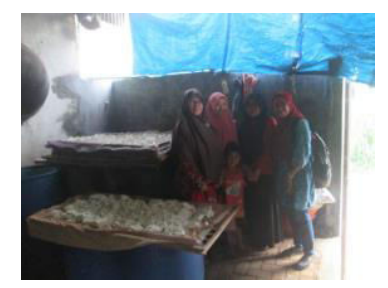

\section{Gambar 1. Bersama mitra PKM}

\section{Koordinasi dengan mitra}

Kegiatan koordinasi sebagai tindak lanjut hasil survey lokasi. Hal ini untuk mensinergikan kegiatan yang telah dicanangkan oleh kelompok PKK, khususnya berkaitan dengan permasalahan pengolahan Singkong yang memiliki nili jual yang rendah namun di sisi lain panen Singkong melimpah, selain itu juga koordinasi terkait kebutuhan alat dan bahan yang diperlukan dalam rangka penerapan teknologi tepat guna melalui pengolahan Singkong berbasis pemanfaatan limbah. Berdasarkan hasil koordinasi ternyata sangat bermanfaat dan memudahkan tim untuk melakukan penyuluhan program ke masyrakat 
dan menambah tali silaturrahim serta memperluas jaringan hubungan baik, bagi Tim PKM maupun institusi Universitas Yudharta Pasuruan.

\section{Pelaksanaan program Penyuluhan tentang singkong}

Singkong merupakan tanaman yang memiliki banyak manfaat kesehatan. Tanaman Singkong memiliki tiga bagian utama, yaitu daun dapat memperbaiki sistem pencernaan, penambah darah dan diet. Bagian umbi Singkong memiliki kalori 2x lipat lebih besar dari Kentang, sehingga umbi tanaman tersebut dapat dijadikan alternatif untuk diet alergi dan diet obesitas. Singkong memiliki kadar pati \pm $35,93 \%$, randemen pati $\pm 18,94 \%$, amilosa \pm $18,03 \%$, amilopektin $\pm 81,97 \%$ dan tingkat konversi pati menjadi glukosa secara enzimatis sebesar $\pm 64,92 \%$. Selain itu, limbah dari tanaman Singkong juga dapat dimanfaatkan untuk bahan pangan, pakan ternak dan bioetanol. Selain berbagai manfaat tersebut, kulit merupakan bagian dari limbah Singkong yang memiliki kandungan senyawa seperti tanin, enzim peroksidase, kalsium oksalat, dan glikosida. Beberapa kandungan lain dari umbi Singkong, di antaranya Vitamin A, Vitamin C, Vitamin B1, Kalsium, fosfor, protein, lemak, hidrat arang danzat besi (Salim, 2012).

Singkong dalam pengolahan bahan pangan telah banyak dikembangkan menjadi tepung. Pengembangkan produk turunan tepung Singkong yaitu tepung mocaf (Modified Cassava Fluor). Prinsip pembuatan tepung mocaf adalah memodifikasi sel Singkong secara fermentasi dengan memanfaatkan mikroba BAL (Bakteri Asam Laktat) yang mampu menghasilkan enzim pektinolitik dan selulolitik serta asam laktat, sehingga tepung yang dihasilkan memiliki karakteristik dan kualitas hampir menyerupai terigu. Penelitian dengan bahan baku ubi kayu untuk pembuatan tepung mocaf telah banyak dilakukan. Pembuatan tepung mocaf dengan fermentasi alami (tanpa penambahan enzim) memerlukan waktu fermentasi selama tiga hari. Sedangkan, pembuatan tepung mocaf dengan penambahan enzim hanya memerlukan waktu fermentasi 24 jam. Enzim merupakan kumpulan dari beberapa spesies mikroba. Sobowale et al. (2007) menggunakan strain Lactobacillus plantarum untuk fermentasi ubi kayu menjadi tepung mocaf dalam waktu 36 jam. Starter Bimo-CF untuk fermentasi Singkong menjadi tepung mocaf hanya memerlukan waktu 12 jam. Berdasarkan hasil penelitian, diketahui bahwa tepung mocaf mengandung antioksidan, protein, serta memiliki amilopektin yang lebih rendah jika dibandingkan dengan tepung pati (Subagio, 2009; Hersoelistyarini et al., 2015; Maghfiroh, 2018). Singkong telah banyak diolah menjadi bahan pangan. Pemanfaatan tidak hanya pada bagian umbi saja, namun limbahnya juga dapat meningkatkan nilai ekonomi dari Singkong. Pengolahan Singkong menjadi bahan pangan, selain dapat meningkatkan nilai ekonomi juga dapat meningkatkan zat gizi dan manfaat kesehatan.

Berdasarkan hasil pelatihan, responden merasa sangat puas dengan kegiatan pengolahan Singkong yang dikenalkan oleh tim PKM. Hal tersebut tampak dari angket yang telah disebar, menunjukkan bahwa dari 30 peserta menyatakan sangat suka sebanyak 24 peserta (80\%), dan suka 6 peserta $(20 \%)$. indikator keberhasilan sosialisasi ini juga dapat diketahui dengan banyaknya pertanyaan yang diajukan oleh peserta. Hal ini menunjukkan antusiasme peserta sangat tinggi terhadap sosialisasi yang diberikan. Kegiatan penyuluhan ini juga dihadiri oleh perwakilan dari pengurus pusat PKK desa Sukopuro. Selain itu, ada 2 mahasiswa yang ikut mendampingi dalam kegiatan penyuluhan ini. 


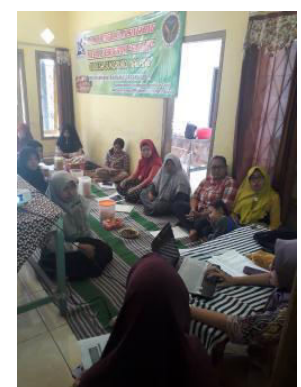

Gambar 2. Kegiatan penyuluhan

Pelatihan pengolahan singkong menjadi produk bergizi berbasis pemanfaatan limbah

Proses pengolahan dan diversifikasi produk Singkong menjadi produk olahan adalah untuk meningkatkan nilai jual Singkong. Lahan warga secara geografis mampu menghasilkan Singkong yang melimpah tanpa kenal musim, namun hal tersebut tidak sebanding dengan pendaoatan warga sekitar. Hal ini disebabkan oleh rendahnya nilai jual SIngkong. Selama ini Singkong dijual dalam bentuk mentah dan olahan setengah jadi dalam bentuk chips kering. Namun penjualan tersebut belum dapat meningkatkan harga jual Singkong. Selain itu pengolahan Singkong menjadi produk setengah jadi juga menghasilkan banyak limbah yang tidak diolah oleh warga. Hanya sebagian kecil warga yang mengolah limbah Singkong menjadi pupuk.

Program kemitraan masyarakat ini dapat membantu warga khususnya ibu - ibu PKK RT 4 RW 1 Loring Sukopuro dalam mengolah Singkong mnejadi produk bergizi tanpa menghasilkan limbah serta memiliki kandungan gizi yang lebih baik jika dibandingkan dengan Singkong yang dikonsumsi secara langsung. Beberapa olahan Singkong yang disosialisasikan dalam kegiatan ini adalah, olahan Singkong menjadi Mie mocaf, Nata de cassava dan gula cair. Pembuatan ketiga produk tersebut disajikan dalam lampiran.
Berdasarkan hasil yang diperoleh dari kuisioner pelatihan pengolahan Singkong menjadi produk bergizi berbasis pemanfaatan limbah, didapatkan hasil bahwa dari data 28 peserta, diperoleh jawaban responden menyatakan bahwa sebanyak 92,85\% (26 peserta) menyatakan terampil dan $7,15 \%$ (2 peserta) menyatakan tidak terampil. Hasil di atas menunjukkan bahwa mitra dapat menerima pelatihan yang diberikan karena dapat menambah pengetahuan pengolahan Singkong yang sebelumnya belum diketahui.

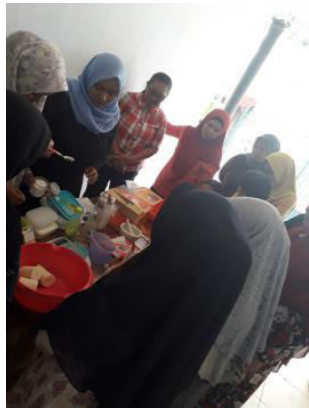

Gambar 3.

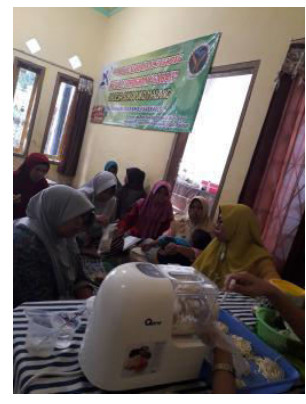

pembuatan olahan singkong

\section{Alih teknologi peralatan tepat guna}

Pengolahan Singkong menjadi produk bergizi berbasis pemanfaatan limbah memerlukan alih teknologi peralatan tepat guna untuk membantu kelancaran warga dalam mengolah Singkong menjadi produk bergizi berbasis pemanfaatan limbah. Proses pengolahan yang baik dapat mempengaruhi kualitas produk yang dihasilkan dan produk yang baik juga dipengaruhi oleh penggunaan teknologi yang tepat. Tim PKM memberikan beberapa jenis alat yang terbagi menjadi 2 kategori, yang pertama alat tersebut berfungsi secara langsung untuk pengolahan produk, beberapa alat yang diberikan kepada mitra di antaranya : Oven, Pasta maker, Mixer gula cair, Pengepres, Refraktometer, Termometer, pemotong Singkong, dan Parut. Kategori kedua merupakan alat pendukung, beberapa di antaranya: Filter air + media dan tandon air + perangkat pipa. Pemberian alat kategori kedua berdasarkan hasil survey Tim, bahwa sumber 
air warga tercemar limbah kotoran ternak sehingga untuk produk olahan yang diproduksi, sulit mendapatkan izin produksi karena berkaitan dengan kandungan mikroba yang terdapat pada produk tersebut. Hal ini tentunya sangat menghambat mitra dalam menghasilkan berbagai macam produk, sehingga Tim PKM memutuskan untuk memberikan bantuan alat pendukung produksi.
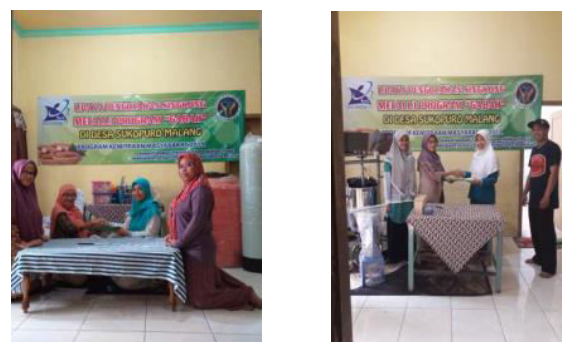

Gambar 4. Serah terima alat yang digunakan untuk transfer teknologi

\section{Pelatihan manajemen dan pemasaran}

Pelatihan manajemen usaha meliputi kegiatan perencanaan, teknik penentuan harga, promosi dan pendistribusian produk olahan Singkong. Selain itu, juga diberikan pelatihan terkait pemasaran yang meliputi daerah pemasaran produk dan teknik penanganan permintaan konsumen, sehingga dengan berjalannya kedua hal tersebut maka dari hasil program ini dalam jangka panjang akan menjadi daerah percontohan produksi olahan Singkong menjadi produk bergizi berbasis pemanfaatan limbah.
Pelatihan manajemen usaha proses pengolahan Singkong, salah satunya yang diberikan dalam bentuk teknik penghitungan analisis usaha. Kemampuan analisis usaha dapat mempengaruhi proses produksi hingga pemasaran. Selain itu, juga diberikan pelatihan berupa contoh perhitungan analisis biaya dari beberapa produk olahan Singkong seperti, mie mocaf, nata de cassava, dan gula cair.

Berdasarkan kuisioner yang diberikan, menunjukkan bahwa 92,85\% (26 orang) mitra menerima pelatihan yang diberikan dan $7,15 \%$ ( 2 orang) mitra tidak dapat menerima materi yang diberikan. Berdasarkan jawaban responden, dapat dijadikan sebagai indikator kepuasan mitra terhadap pelatihan manajemen dan pemasaran. Selain itu, juga dapat diketahui melalui pertanyaan yang diberikan warga pada saat pelatihan. Program kemitraan masyarakat ini diharapkan secara mandiri mampu medorong masyarakat memiliki kemampuan analisis usaha, penghitungan biaya produksi, serta strategi pemasaran agar produk dapat dikenal masyarakat secara lebih luas.

Berikut merupakan tabel hasil kuisioner yang diberikan pada mitra setelah pelaksanaan program. Selain itu juga disajikan tabel terkait luaran program pengabdian kepada masyarakat.

Tabel 1. Hasil kuisioner terhadap mitra setelah pelaksanaan program pengabdian

\begin{tabular}{|c|c|c|c|c|}
\hline No & Program / materi & Keterangan Peserta & Peserta & Presentase \\
\hline \multirow[t]{2}{*}{1} & \multirow{2}{*}{$\begin{array}{l}\text { Penyuluhan tentang Singkong dan } \\
\text { manfaatnya }\end{array}$} & Tahu & 24 & $80 \%$ \\
\hline & & Tidak tahu & 6 & $20 \%$ \\
\hline \multirow[t]{2}{*}{2} & \multirow{2}{*}{$\begin{array}{l}\text { Pelatihan pengolahan Singkong menjadi } \\
\text { produk bergizi berbasis pemanfaatan } \\
\text { limbah }\end{array}$} & Terampil & 26 & $92.85 \%$ \\
\hline & & Tidak terampil & 2 & $7,15 \%$ \\
\hline \multirow[t]{2}{*}{3} & \multirow[t]{2}{*}{ Alih teknologi peralatan tepat guna } & Menerima & 28 & $100 \%$ \\
\hline & & Tidak menerima & 0 & $0 \%$ \\
\hline \multirow[t]{2}{*}{4} & \multirow[t]{2}{*}{ Pelatihan manajemen dan pemasaran } & Menerima & 26 & $92.85 \%$ \\
\hline & & Tidak menerima & 2 & $7,15 \%$ \\
\hline \multirow[t]{2}{*}{5} & \multirow{2}{*}{$\begin{array}{l}\text { Ketertarikan mitra membuat produk } \\
\text { olahan Singkong }\end{array}$} & Minat & 26 & $92.85 \%$ \\
\hline & & Tidak minat & 2 & $7,15 \%$ \\
\hline
\end{tabular}


Tabel 2. Luaran program pengabdian kepada masyarakat

\begin{tabular}{|c|c|c|c|}
\hline No & Kegiatan & Indikator Kerja & Luaran \\
\hline 1 & $\begin{array}{l}\text { Penyuluhan tentang Singkong } \\
\text { dan manfaatnya serta proses } \\
\text { pengolahan mie mocaf dan } \\
\text { olahan Singkong }\end{array}$ & $\begin{array}{l}\text { Peningkatan pengetahuan mitra terhadap } \\
\text { manfaat Singkong dan kemampuan } \\
\text { mitra tentang pengolahan Singkong }\end{array}$ & \\
\hline 2 & $\begin{array}{l}\text { Praktik pengolahan mie mocaf, } \\
\text { nata de cassava, dan gula cair }\end{array}$ & $\begin{array}{l}\text { Peningkatan keterampilan mitra dalam } \\
\text { mengolah Singkong menjadi mie mocaf, } \\
\text { nata de cassava, dan gula cair }\end{array}$ & Produk \\
\hline 3 & $\begin{array}{l}\text { Alih teknologi peralatan tepat } \\
\text { guna }\end{array}$ & $\begin{array}{l}\text { Menerima peralatan produksi yang tepat } \\
\text { guna }\end{array}$ & $\begin{array}{l}\text { Alat produksi mie } \\
\text { mocaf, nata de } \\
\text { cassava dan gula } \\
\text { cair }\end{array}$ \\
\hline 4 & $\begin{array}{l}\text { Pelatihan manajemen dan } \\
\text { pemasaran }\end{array}$ & $\begin{array}{l}\text { Peningkatan kemampuan manajemen } \\
\text { dan pemasaran mitra }\end{array}$ & \\
\hline 5 & $\begin{array}{l}\text { Ketertarikan mitra membuat } \\
\text { produk olahan Singkong }\end{array}$ & $\begin{array}{l}\text { Ketertarikan mitra membuat olahan } \\
\text { Singkong }\end{array}$ & $\begin{array}{l}\text { Produksi mie } \\
\text { mocaf, nata de } \\
\text { cassava, dan gula } \\
\text { cair }\end{array}$ \\
\hline
\end{tabular}

Tabel 1 menjelaskan tentang indicator keberhasilan program berdasarkan skor yang diperoleh dari pengisian kuisioner setelah kegiatan pelatihan. Tabel tersebut juga dapat menjelaskan sejauh mana kegiatan pada program kemitraan masyarkat dapat diterima oleh mitra. Kemudian tabel 2 menjelaskan luaran yag dihasilkan dari kegiatan program kemitraan masyarakat, berupa transfer teknologi pengolahan Singkongn untuk meningkatkan nilai ekonomi dan gizi Singkong.

\section{KESIMPULAN DAN SARAN}

\section{Kesimpulan}

Berdasarkan program yang telah dilaksanakan, maka dapat disimpulkan sebagai berikut:

1. Secara umum mitra dapat menerima transfer teknologi dengan baik

2. Kegiatan penyuluhan dan pelatihan pembuatan produk dapat diterima oleh mitra dan masyarakat berdasarkan hasil survey kepuasan

3. Mitra dan masyarakat mampu memanfaatkan alat teknologi tepat guna yang diberikan oleh tim
4. Peningkatan pemahaman mengenai pengolahan produk, manajemen keuangan serta pemasaran yang telah diberikan.

\section{Saran}

1. Perlunya pendampingan berkelanjutan agar program dapat berjalan sesuai rencana

2. Perlunya pendampingan izin usaha agar produk yang dihasilkan dapat dipercaya oleh konsumen.

\section{DAFTAR PUSTAKA}

Buckle, K.A., Edwards, R.A., Fleet, G.H., \& Wootton, M.(2009). Ilmu pangan. Penerjemah H. Purnomo dan Adiono. Jakarta:UI-Press

Charles, A.L., Chang, Y.H, Ko, W.C., Sriroth, K., \& Huang, T.C. (2005). Influence of amylopectin structure and amylose content on gelling properties of five cultivars of cassava starches. Journal of Agriculture and Food Chemistry,53,2717-2725.

Departemen Kesehatan R.I. (1972). Pati singkong. Bhratara Karya Aksara: Jakarta 
Hersoelistyorini, W., Dewi, S. S., \& Kumoro, A. C. (2015). Sifat fisikokimia dan organoleptik tepung mocaf (modified cassava flour) dengan fermentasi menggunakan ekstrak kubis.

Maghfiroh, K., \& Roisatul, A. (2018). Karakterisasi Beras Analog Berbahan baku Mocaf Terfermentasi Ekstrak Kubis Berbeda dengan Fortifikasi Spirulina. Proceeding SEMNAS ke 3 Unmuh Kupang.

Misgiyarta .(2013). Produksi nata de cassava dengan substrat limbah cair tapioka. Balai Besar Penelitian dan Pengembangan Pascapanen Pertanian.

Pratama, A.J. (2015). Studi produksi gula cair untuk peninggkatan budidaya dan pascapanen sagu (metroxylon spp.) asal Sorong Selatan. Skripsi: Institut Pertanian Bogor.

Putra, H.P., \& Ivan, M. (2012). Optimalisasi penggunaan substrat dan penambahan enzim alphaamilase dan glukoamilase pada proses hidrolisis kulit singkong. Proceeding The 3 rd International Conference on Sustainable: ISBN 978979-98438-7-6. Universitas Islam Indonesia.

Rahmawati, N., Retni S.B., \& Harlis. (2017). Kajian pembuatan gula cair berbahan dasar kulit singkong (manihot utilisima) dengan pemanfaatan bakteri bacillus licheniformis. Pendidikan Biologi Universitas Jambi.
Riki, D.M.R., Andreas, P., Jos, B., \& Sumardiono, S. (2013). Modifikasi ubi kayu dengan proses fermentasi menggunakan starter Lactobacillus casei untuk produk pangan. Jurnal Teknologi Kimia dan Industri, 2(4), 137-145.

Rosmeri, V. I., Monica, B. N., \& Budiyati, C. S. (2013). Pemanfaatan tepung umbi gadung (dioscorea hispida dennst) dan tepung mocaf (modified cassava flour) sebagai bahansubstitusidalam pembuatan mie basah, mie kering, dan mie instan. Jurnal Teknologi Kimia dan Industri, 246-256.

Salim, E. (2012). Sukses bisnis nata de cassava skala rumah tangga. Yogyakarta : Lily Publisher.

Subagio, A. (2009). Mocaf: inovasi dan peluang baru. Trubus, Agustus 2009/XL ISSN-0128-005i.

Yunianta, Y., Sulistyo, T., Apriliastuti, A., Estiasih, T., \& Wulan, S. N. (2012). Synergistic amylase, ahydrolysis of arrowroot (marantha arundinaceae 1.) starch by glucoamylase, and pullulanase for glucose syrup production. Jurnal Teknologi Pertanian, 11(2).

Zulaidah, A. 2011. Modifikasi ubi kayu secara biologi menggunakan starter bimo-cf menjadi tepung termodifikasi pengganti gandum. Tesis Magister Teknik Kimia Universitas

Diponegoro. 